\title{
Determination of ascorbic acid content of some tropical fruits by iodometric titration
}

\author{
I. J. DIOHA ${ }^{1 *}$, O. OLUGBEMI ${ }^{1}$, T. U. ONUEGBU ${ }^{2}$ and Z. SHAHRU ${ }^{3}$ \\ ${ }^{1}$ Energy Commission of Nigeria, Plot 701C, Central Area, P.M.B. 358 Garki, Abuja, Nigeria. \\ ${ }^{2}$ Department of Pure and Industrial Chemistry, Nnamdi Azikwe University, Awka, Nigeria. \\ ${ }^{3}$ Department of Chemistry, Kano State University of Science and Technology, Kano, Nigeria. \\ *Corresponding author, E-mail: diohaij@yahoo.com
}

\begin{abstract}
The ascorbic acid content of three common juicy tropical fruits, orange, water melon and cashew, were determined using iodometric titration method under three temperature regimes (refrigerated, room temperature, and heated to about $80{ }^{\circ} \mathrm{C}$ ), representing the range of temperatures the fruits may be exposed to during processing and storage. It was observed that fruits exposed to higher temperature contained the least of the ascorbic acid. This is as a result of increase in oxidation of ascorbic acid with increase in temperature, as higher temperature favours redox reaction. Refrigerated orange gave an ascorbic acid value of $43.80 \mathrm{mg} / \mathrm{cm}^{3}$, room temperature had $41.84 \mathrm{mg} / \mathrm{cm}^{3}$, while the heated $\left(80^{\circ} \mathrm{C}\right)$ orange contained $39 \mathrm{mg} / \mathrm{cm}^{3}$. Water melon contained $27.30 \mathrm{mg} / \mathrm{cm}^{3}, 27.05 \mathrm{mg} / \mathrm{cm}^{3}$ and $25.68 \mathrm{mg} / \mathrm{cm}^{3}$ for refrigerated, room temperature and heated fruits respectively. Cashew contained the highest ascorbic acid with $213.62 \mathrm{mg} / \mathrm{cm}^{3}, 211.79 \mathrm{mg} / \mathrm{cm}^{3}$ and 210.55 $\mathrm{mg} / \mathrm{cm}^{3}$ for refrigerated, room temperature and heated fruits respectively.
\end{abstract}

(C) 2011 International Formulae Group. All rights reserved.

Keywords: Ascorbic acid, iodometric titration, vitamin C, temperature, orange, water melon, cashew.

\section{INTRODUCTION}

Ascorbic acid (AA) is a water-soluble substance, which occurs in fruits and many vegetables. One form of ascorbic acid is known as Vitamin $\mathrm{C}$. The human disease caused by a deficiency of vitamin $\mathrm{C}$ is scurvy. The name is derived from scorbutus. Vitamin $\mathrm{C}$ cannot be synthesized by some mammalian groups of animals including human beings yet plays an important role in their metabolic processes. AA plays an important role in collagen biosynthesis, iron absorption, and immune response activation, and is involved in wound healing and osteogenesis. It also acts as a powerful antioxidant which helps fight against free-radical induced diseases. In plants, it is essential for photosynthetic activity during the detoxification of superoxide and hydrogen peroxide in chloroplasts, in the absence of catalase. AA is also involved in the regeneration of $\alpha$ tocopherol. It is an anti-darkening substance in food because of its antioxidation properties (Cioroi, 2006).

Ascorbic acid owes its acidic properties and ease of oxidation to the presence of enediol grouping (Izuagie and Izuagie, 2007). It behaves as a vinylogous carboxylic acid where the electrons in the double bond, hydroxyl group lone pair, and the carbonyl 
double bond form a conjugated system. Because the two major resonance structures stabilize the deprotonated conjugate base of ascorbic acid, the hydroxyl group in ascorbic acid is much more acidic than typical hydroxyl groups. In other words, ascorbic acid can be considered an enol where the deprotonated form is a stabilized enolate.

Ascorbic acid also interconverts into two unstable ketone tautomers by proton transfer, although it is the most stable in the enol form. When the proton of the hydroxyl of the enol is removed, a pair of electrons from the resulting oxide anion pushes down to form the ketone at the 2 or 3 position and the electrons from the double bond move to the 3 or 2 position, respectively, forming the carbanion, which picks up the proton resulting in two possible forms: 1carboxyl-2-ketone and 1-carboxyl-3-ketone.

Various reports have shown fruits to be excellent sources of vitamin C. Among fruits that have been reported to contain considerably high level of vitamin $\mathrm{C}$ are citrus, tomatoes, strawberries, peppers, grapefruit, guava, etc (Hwang, 1999; Okiei et al., 2009). There is however occasional wide variation in results of different investigators. For instance, Cioroi (2007) reported fresh lemon, orange and grape fruit to contain 51.78 $\mathrm{mg} / 100 \mathrm{~g}, 56.02 \mathrm{mg} / 100 \mathrm{~g}$ and $48.01 \mathrm{mg} / 100$ $\mathrm{g}$ respectively. This is slightly different from the report of Okiei et al. (2009) which gave the ascorbic acid content of lemon, orange and grape fruits as $49.00 \mathrm{mg} / 100 \mathrm{~g}, 64.00 \mathrm{mg} / 100$ $\mathrm{g}$ and $68.75 \mathrm{mg} / 100 \mathrm{~g}$ respectively.

The variations in reports have been attributed to a number of factors that may affect the ascorbic acid levels in fruits. These include climate, temperature and soil nutrients. The composition of plant tissues during growth and development is also determined by temperature which varies from region to region. For example, grapefruits grown in the coastal region of California have been reported to contain more vitamin $\mathrm{C}$ than those grown in the desert areas of California and Arizona (Lee and Kader, 2000).

The objective of this study was to determine the ascorbic acid content of three common juicy tropical fruits using iodometric titration method under three temperature regimes representing the ranges the fruits may be exposed to during processing and storage. The redox reaction is preferable to an acidbase titration because a number of other species in juice can act as acids. This work helped to demonstrate the effects of processing and storage on the ascorbic acid contents of these fruits.<smiles>O=C1C(O)=C([O-])O[C@@H]1[C@@H](O)CO</smiles>

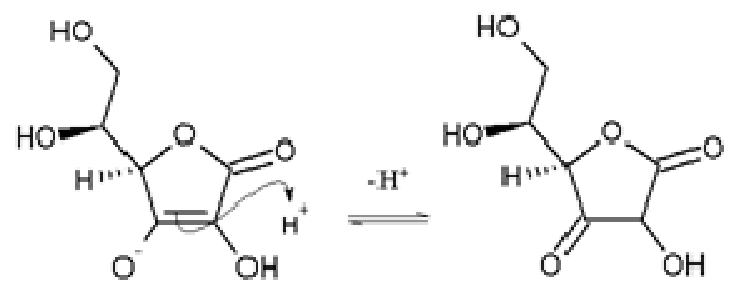




\section{MATERIALS AND METHODS Preparation of reagents}

To obtain $10 \%$ potasium iodide needed, $10 \mathrm{~g}$ of potassium iodide was weighed and diluted in $100 \mathrm{ml}$ of distilled water. $16.8 \mathrm{ml}$ of $98 \%$ sulphuric acid was measured and poured into 1 litre of distilled water to obtain $0.3 \mathrm{M}$. In order to obtain the $1 \mathrm{M}$ potassium iodate (KIO3) required, $2.14 \mathrm{~g}$ of KIO3 powder was weighed and diluted in 1 litre of distilled water. $2.48 \mathrm{~g}$ of sodium thiosulphate crystals was diluted in 1 litre of distilled water to obtain $0.1 \mathrm{M}$ of the reagent required.

\section{Sample preparation}

Fresh samples of orange, water melon, and cashew were obtained from a regular market in Kano, Nigeria. The samples were washed and classified into three groups for storage, with each group containing ten samples of each fruit. The first group of fruits were refrigerated for 24 hours and allowed to settle. The second group of fruits were heated for 10 minutes at a temperature of $80{ }^{\circ} \mathrm{C}$ and allowed to cool while the third group was stored at an average room temperature of about $25{ }^{\circ} \mathrm{C}$ for 12 hours. The orange samples were washed again with distilled water, peeled and sliced into two transversely, and squeezed. The juice obtained was filtered with a muslin cloth. The water melon samples were sliced into smaller portions and squeezed. The juice obtained was also filtered. The same treatment was applied to the cashew fruit samples.

\section{Procedures for ascorbic acid determination in samples}

$10 \mathrm{ml}$ of each of the fruit samples was pipetted into a pre-washed conical flask and 5 $\mathrm{ml}$ of $10 \%$ potassium iodide (KI) with $2 \mathrm{ml}$ of $0.3 \mathrm{M}$ sulphuric acid $\left(\mathrm{H}_{2} \mathrm{SO}_{4}\right)$ were added into the flask. $10 \mathrm{ml}$ of $0.01 \mathrm{M}$ potassium iodate $\left(\mathrm{KIO}_{3}\right)$ was also added into the flask. The excess iodine generated was titrated against $0.01 \mathrm{M}$ sodium thiosulphate $\left(\mathrm{Na}_{2} \mathrm{~S}_{2} \mathrm{O}_{3}\right)$ solution. Blank titration was carried out with $10 \mathrm{ml}$ of distilled water.

$$
\begin{aligned}
& \text { Equations for the reaction } \\
& \mathrm{IO}_{3 \text { (aq) }}^{-}+5 \mathrm{I}_{(\mathrm{aq})}+6 \mathrm{H}_{(\text {aq) }}^{+} \longrightarrow 3 \mathrm{I}_{2(\mathrm{aq})}+3 \mathrm{H}_{2} \mathrm{O}_{\text {(aq }} \\
& \underset{\text { Ascorbic acid }}{\mathrm{C}_{6} \mathrm{H}_{8} \mathrm{O}_{6(\text { aq }}}+\mathrm{I}_{2 \text { (aq) }} \longrightarrow \underset{\text { dehydroascorbic acid }}{\mathrm{C}_{6} \mathrm{H}_{6} \mathrm{O}_{6(\text { aq) }}}+2^{-} \mathrm{I}_{(\text {aq })}+2 \mathrm{H}^{+} \\
& \mathrm{I}_{2(\mathrm{aq})}+\mathrm{S}_{2} \mathrm{O}_{3}{ }^{2-} \text { (aq) } \rightleftharpoons 2 \mathrm{I}_{(\mathrm{aq})}^{-}+\mathrm{S}_{2} \mathrm{O}_{3}{ }^{2-} \text { (aq) }
\end{aligned}
$$

\section{RESULTS AND DISCUSSION}

The average titre value of each sample was deducted from the average titre value of the blank titration (Table 1) to obtain the actual volume of $\mathrm{S}_{2} \mathrm{O}_{3}{ }^{2-}$ (aq) absorbed by the ascorbic acid (Table 2). From the results obtained, the molarity and concentration of ascorbic acid in $\mathrm{mg}$ per $\mathrm{cm} 3$ in each sample were obtained using the relationships below:

$M I_{2}=\frac{M S_{2} O_{g}{ }^{n-} \times V S_{2} O_{g}{ }^{n-} \times n L_{2}}{V l_{2} \times n S_{2} O_{2}{ }^{2-}}$

$\mathrm{MS}_{2} \mathrm{O}_{3}{ }^{2-}=$ Mole of Sadim Thiosulphate

(0.01)

$V I_{2}=$ Volume of lodine

${ }_{n} \mathrm{~S}_{2} \mathrm{O}_{3}{ }^{2-}=$ Number of Thiosulphate (1)

$\mathrm{VS}_{2} \mathrm{O}_{3}{ }^{2-}=$ Volume of Thiosulphate absorbed

$n I_{2}=$ Number of Iodine (1)

Conc. of AA $\left(\right.$ mgcm- $\left.^{3}\right)=$ $\left(\mathrm{MI}_{2} \times\right.$ Molar Mass of $\left.\mathrm{AA}\right) \times 100$

The results of amount of ascorbic acid absorbed are shown in Table 3. The difference in the amount of ascorbic acid absorbed in each of the fruit type could be attributed to the different temperatures the fruits were exposed to. It was observed that fruits exposed to higher temperature absorbed the least of the ascorbic acid and vice versa. This is as a result of increase in oxidation of ascorbic acid with increase in temperature, as higher temperature favours redox reaction. 
Ascorbic acid obtained for water melon in this study compares favourably with those reported by USDA Nutrient Database for standard reference, 2002. The values obtained for orange are also in agreement with the range reported by Rahman (2002). The values obtained for cashew are in agreement with those reported by Akinwale (1991), Lowor and Agyante-Badu (2009) and Association of Official Analytical Chemists, Washington DC, USA.

The deviation of this result from those reported by some other researchers for some of the fruit samples analysed may be as a result of some of the other factors that affect the ascorbic acid level in fruits. These factors include climate, degree of ripeness and the amount of fertilizer used in cultivation. Climatic conditions such as light and temperature have been reported to affect the chemical composition of horticultural crops (Klein and Perr, 1982). Different experimental procedures may also yield different results. For instance, Razmi and Harasi (2008) using a cadmium pentacyanonitrosylferrate film modified carbon electrode obtained ascorbic acid values of $49.24 \mathrm{mg} / 100 \mathrm{~cm}^{3}$ and 8.80 $\mathrm{mg} / 100 \mathrm{~cm}^{3}$ for orange and grape respectively. But Lim et al. (2006) using reversed phase HPLC technique reported ascorbic acid content of $144 \mathrm{mg} / 100 \mathrm{~g}$ for guava and Vanderslice et al. (1990) reported ascorbic acid level of $23.60 \mathrm{mg} / 100 \mathrm{~g}$ of grape.

Table 1: Average titre values for blank and samples titrations.

\begin{tabular}{llllll}
\hline S/N & Sample & & Average titre value $\left(\mathbf{c m}^{\mathbf{3}}\right)$ & \\
\hline 0 & Distilled water & & 55.82 & & \\
& & & & & \\
& Common name & Botanical name & Refrigerated & Room temp. & Heated $\left(\mathbf{8 0}^{\mathbf{0}} \mathbf{C}\right)$ \\
1 & Orange & Citrus sinensis & 49.10 & 49.49 & 49.82 \\
2 & Water melon & Citrullus vulgaris L. & 51.62 & 51.67 & 51.88 \\
3 & Cashew & Anacardium occidentale & 23.05 & 23.33 & 23.52 \\
\hline
\end{tabular}

Table 2: The actual volume of $\mathrm{S}_{2} \mathrm{O}_{3}{ }^{2-}(\mathrm{aq})$ absorbed in the mixture.

\begin{tabular}{llllll}
\hline \multirow{2}{*}{ S/N } & Sample & & \multicolumn{3}{c}{ Volume of $\mathbf{S}_{\mathbf{2}} \mathbf{O}_{\mathbf{3}}{ }^{2-}$ (aq) absorbed by $\mathbf{A A}\left(\mathbf{c m}^{\mathbf{3}}\right)$} \\
\cline { 2 - 5 } & Common name & Botanical name & Refrigerated & Room temp. & Heated $\left(\mathbf{8 0}^{\mathbf{0}} \mathbf{C}\right)$ \\
\hline \multirow{2}{*}{ Orange } & Citrus sinensis & 43.80 & 41.84 & 39.00 \\
& Water melon & Citrullus vulgaris L. & 27.30 & 27.05 & 25.68 \\
Cashew & Anacardium occidentale & 213.62 & 211.79 & 210.55 \\
\hline
\end{tabular}

Table 3: Ascorbic acid content of some tropical fruit samples obtained by iodometric titration.

\begin{tabular}{|c|c|c|c|c|c|}
\hline \multirow{2}{*}{$\mathbf{S} / \mathbf{N}$} & \multicolumn{2}{|l|}{ Sample } & \multicolumn{3}{|c|}{ Amount of ascorbic acid $\left(\mathrm{mg} / \mathrm{cm}^{3}\right)$} \\
\hline & Common name & Botanical name & Refrigerated & Room temp. & Heated $\left(80^{\circ} \mathrm{C}\right)$ \\
\hline 1 & Orange & Citrus sinensis & 43.80 & 41.84 & 39.00 \\
\hline 2 & Water Melon & Citrullus vulgaris L. & 27.30 & 27.05 & 25.68 \\
\hline 3 & Cashew & Anacardium occidentale & 213.62 & 211.79 & 210.55 \\
\hline
\end{tabular}




\section{Conclusion}

Determination of ascorbic acid content by iodometric titration is an easy, safe, and fast method. This would help in quickly determining an estimate of ascorbic acid content of fruits for the purpose of recommending them for consumption to curb deficiency problems. Adequate consumption of fruits with high level of vitamin C can help in health improvement and thus reduce diseases such as diabetes, glaucoma, atherosclerosis, stroke, heart diseases and cancer that are prevalent in Africa.

\section{REFERENCES}

Akinwale TO. 2000. Cashew apple juice: Its use in fortifying the nutritional quality of some tropical fruits. European Food Research and Technology, 211: 205207.

Cioroi M. 2006. Analytical Chemistry, Gravimetry and Volumetry. Ars Docenti: Bucharest.

Cioroi M. 2007. Study on L-Ascorbic acid contents from exotic fruits. Cercetari Agronomice in Moldva, Anul XXXX, 1: 23-27.

Hwang MY. 1999. How much vitamin C do you need? The Journal of the American Medical Association, 281(15): 1640.

Izuagie AA, Izuagie FO. 2007. Iodometric determination of ascorbic acid (vitamin C) in citrus fruits. Research Journal of Agricultural and Biological Sciences, 3(5): 367 - 369 .

Klein BP, Perry AK. 1982. Ascorbic-acid and vitamin-activity in selected vegetables from different geographical areas of the United-States. Journal of Food Science, 47: 941-945.
Lee SK, Kader AA. 2000. Preharvest and postharvest factors influencing vitamin $\mathrm{C}$ content of horticultural crops. Postharvest Biology and Technology, 20: 207-220.

Lowor ST, Agyente-Badu CK. 2009. Mineral and proximate composition of cashew apple (Anarcadium occidentale L.) juice from Northern savannah, forest and coastal savannah regions in Ghana. American Journal of Food Technology, 4(4): 154 - 161.

Okiei W, Ogunlesi M, Azeez L, Obakachi V, Osunsanmi M, Nkenchor G. 2008. The voltammetric and titrimetric determination of ascorbic acid levels in tropical fruit samples. International Journal of Electrochemical Science, 4: 276-287.

Rahman MM, Khan MM, Hosain MM. 2007. Analysis of vitamin C (ascorbic acid) contents in various fruits and vegetables by UV-spectrophotometry. Bangladesh J. Sci. Ind. Res., 42(4): 417 - 424.

Razmi H, Harasi M. 2008. Voltammetric behavior and amperometric determination of ascorbic acid at cadmium pentacyanonitrosylferrate film modified GC electrode. Int. J. Electrochem. Sci., 3: 81-94.

U.S. Department of Agriculture, U.S. Department of Health and Human Services. Your Health: Dietary Guidelines for Americans, 4th Ed. Home and Garden bulletin No. 232. U.S. Government Printing office, Washington D.C.

Vanderslice JT, Higgs DJ, Hayes JM, Block G. 1990. Ascorbic acid and dehydroascorbic acid content of food-aseaten. J. Food Comp. Anal., 3: 105 - 118. 